\title{
Analysing the Effect of Authentic Learning Activities on Achievement in Social Studies and Attitudes towards Geographic Information System (GIS)
}

\author{
Gökmen Güneş \\ Doctoral Student, Graduate School of Educational Sciences, Gazi University, Ankara, Turkey \\ ORCID:0000-0001-8112-8062
}

\author{
Alaattin Arıkan* \\ Res. Assist., Department of Social Studies Education, Faculty of Education, Aydin Adnan \\ Menderes University, Aydin, Turkey, 10000-0003-0211-2009
}

Turhan Çetin

Prof. Dr., Department of Social Studies Education, Gazi Faculty of Education, Gazi University, Ankara, Turkey ORCID:0000-0002-2229-5255

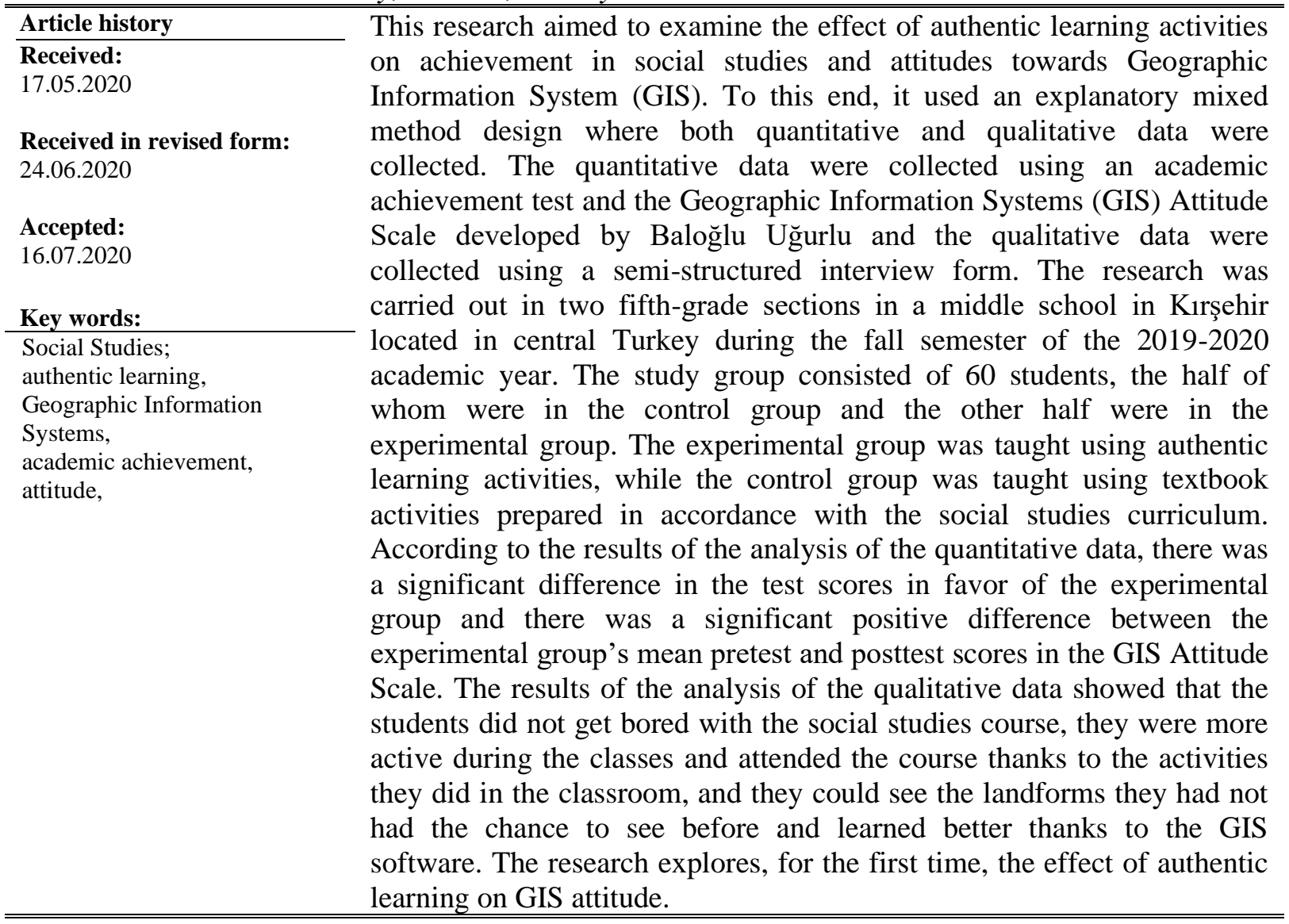

\footnotetext{
*Correspondency: alaattin.arikan@adu.edu.tr
} 


\section{Introduction}

A significant portion of the knowledge, skills and values to be acquired by students are taught especially in social studies classes in primary schools (Çelik, Esmer, \& Y1lmaz, 2016; Kılıçoğlu, 2014). The main purpose of social studies is to help students acquire certain skills and behaviours to know their duties and responsibilities towards the environment, society and humanity, to find solutions to social problems, and to fulfil their social responsibilities (Aykaç, 2007). However, living conditions are changing rapidly. With such changes, daily life is getting more complex everyday (Baysal, Çarıkçı, \& Yaşar, 2018). The way to adapt to today's conditions is through the ability to reach the information needed, to organize, use and develop this information in different ways, to be well equipped with higher-level skills, and to become efficient and productive (Akkuş, 2015).

Several techniques have been proposed and used to help students gain and practice high-order and scientific thinking skills (Altın, 2019). Today, most learning approaches encourage students to study outside the classroom. Out-of-class activities can be carried out in the classroom thanks to today's sources, such as technology and applications (Altın \& Atç1, 2012). Learning can be effective and permanent when activities are similar to real-life situations. In fact, authentic learning activities can make significant contributions to the learning environment. Authentic learning has its roots in situated learning (Herrington \& Oliver, 2000; Gulikers, Bastiaens, \& Martens, 2005; Herrington, Reeves, \& Oliver, 2010). Figure 1 displays the theoretical structure of authentic learning.

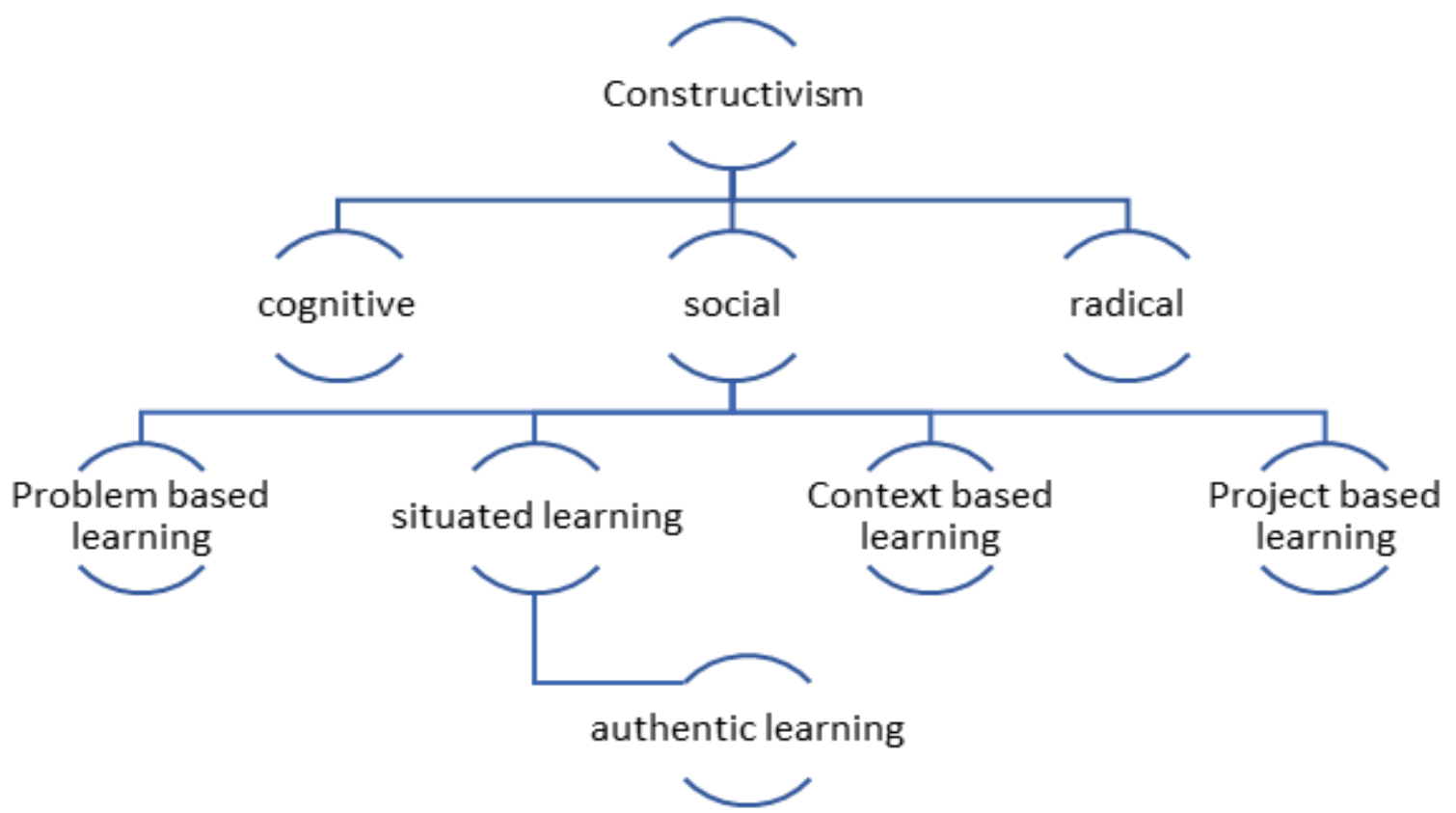

Figure 1. Theoretical Structure of Authentic Learning

As shown in Figure 1, the authentic learning model is included in the situational learning approach. It is thus thought that the terms approach or theory should not be used for authentic learning. It would actually be more appropriate to use the term model for authentic learning. A variety of teaching strategies and methods can be used within the authentic learning model, such as presentation, invention, research, lecture, question-answer, discussion, case studies, demonstration, problem-solving, and individual, group learning, and out-of-class teaching 
techniques. In line with the national literature, the methods and techniques used with the authentic learning model include problem-based learning, project-based learning, inquirybased learning, situated learning, cooperative learning, and connected learning. However, all these are not methods or techniques per se, but learning/teaching approaches.

Situated learning is defined as learning knowledge, skills, and attitudes within a context (Ataizi \& Şimşek, 1999; 255). The paper "Situated Cognition and the Culture of Learning" published by Brown, Collins, and Duguid in 1989 is considered important in the emergence of the situated learning approach. However, situated learning was first was put forward by Jean Lave and is based on the concept of situated cognition, which refers to the situation encountered within a social structure. As people solve the problems faced at work in a context, cognitive apprenticeship involves students' interaction with knowledge and the meaningful use of that knowledge in a context. In other words, situated learning focuses on the importance of teaching practices in everyday life through context as in the apprenticeship system (Herrington \& Oliver, 1995). To illustrate, tailor apprentices gain experience in cutting out and sewing by ironing finished clothes and ironing is a simple, valuable, and certainly real activity (Lave \& Wenger, 2003; 66).

Situated learning has eight basic components: "stories", "reflection", "cognitive apprenticeship", "collaboration", "coaching”, "multiple practice”, "articulation of learning skills", and "technology". These components must be considered in order for learning to be effective when using the situated learning approach in a learning environment (Bozu, 2014; 22).

Interaction is another concept that situated learning values. Teachers need to encourage students to learn by interacting with each other in a social environment (K1lıç, 2015; 20). People construct their knowledge through seeing the perspectives, experiences and ways of understanding of other people around them. Knowledge is not absolute but part of the culture of the social environment in which it exists (K1lıç, 2004). Learning best takes place within a context; thus, artificial and isolated school environments are incomplete as they fail to provide a context for learning. Situated cognition suggests that what is learned should be associated with the interests and needs of learners. Learning is the meaning inferred from authentic situations in everyday life. Therefore, subjects should be associated with students' lives and taught through real-life contexts (Keskin, 2017). Situated learning emphasises that learning environments should offer rich contexts that reflect the real world and daily life and give students the opportunity to apply their knowledge to use it in environments similar to authentic environments. Students can thereby use the given information in environments as close to reality as possible and make connections between different situations. This provides a deep understanding of the newly learned information facilitating the transfer of information to other areas where necessary. Faced with complex problems of the real world during the learning process, students are expected to complete their tasks while benefiting from expert support (Gökdaş, 2003).

In the authentic learning model developed within the situational learning approach, teachers seek to make the learning situation meaningful to students' life and relate it to real-life events in order to help students better structure the information. Thus, the learning process becomes more meaningful, more effective, and more constructive (Firat, 2008). Authentic learning attempts to ensure meaningful and permanent learning, addressing the necessity that learning must be related to real and daily life (Yalvaç Hastürk, 2013). Authentic learning is a process that starts with authentic tasks and continues with authentic activities and evaluations (Dilmaç 
\& Dilmaç, 2014). The issues to be considered in the implementation of the curriculum updated by the Ministry of National Education in Turkey in 2018 include the following statement: "By means of events inside and outside the school, students should often be exposed to real-life problems and dilemmas and encouraged to apply reflective thinking on social problems that they face". Social studies is a course that by nature relies on real-life subjects to prepare students for social life. Social studies indeed is the most suitable course to prepare students for social life in an individual and social context to overcome real-life problems (Duman \& İkiel, 2002). Students prepare for social life with real-life practices, that is, through the social studies course (Yalçınkaya \& Azrak, 2016). Therefore, the authentic learning model seems to be strongly associated with the social studies course in terms of teaching and evaluating subjects. The Unit "People, Places and Environments" in the FifthGrade Social Studies Curriculum was selected to carry out the experimental procedure in this study. The unit addresses the subjects and situations that students personally experience almost every day, such as "Landforms, the Impact of Climate on Human Activities, Population and Settlement, Disasters and Environmental Problems, and the Impact of Natural Disasters on Our Lives". Kab and Açıkalın (2016) note that knowledge and experiences that courses aim at can be gained through practices in schools and understanding real life is possible only through participation-oriented experiences that touch students' life, that is to say, through real and authentic learning. Thusly, the authentic learning model is thought to be instrumental in achieving the learning outcomes of the unit.

Most of the previous studies on authentic learning have focused on science, mathematics and language education (Akça \& Ata, 2009; Aydın, 2019; Aynas, 2018; Bektaş \& Horzum, 2014; Belaid \& Murray, 2015; Belet, Boyac1, \& Güner, 2017; Coşkun, Doğan, \& Ulua, 2017; Cotofana \& Lachman, 2020; Dadl1, 2017; Dennis \& O'Hair, 2010; Dolapçığlu, 2015; Finch \& Jefferson, 2013; Flanagan, 2014; Gençoğlan, 2017; Gregory, 2013; Gündoğan \& Gültekin, 2017; Hamurcu, 2016; Herrington \& Oliver, 2000; Herrington, Reeves, \& Oliver, 2014; Hürsen, 2016; Karakoç, 2016; Koçyiğit \& Zembat, 2013; Motlhaka, 2014; Newmann \& Wehlage, 1993; Preus, 2012; Rule, 2006; Safuan \& Soh, 2013; SAYE the Social Studies Inquiry Research Collaborative, 2013; Weninger, 2018; Westberg \& Leppien, 2018; Yanti \& Mulyono, 2020). However, in Turkey, very few studies have been conducted in the field of social studies education (Baştürk, 2019; Gürgil, 2018; İneç, 2017; İneç \& Akpınar, 2017; Karakuş, 2006; Önger, 2019).

Akpınar and İneç (2017) suggested that authentic learning can be realised using scenario-, evidence- and research-based teaching approaches thanks to the integration of new information technologies into the teaching environment. Their study also made experimentation possible in social studies thanks to technology. Baştürk (2019) emphasised that authentic learning activities contribute to the development of critical thinking skills while improving attitude towards the course. Karakuş (2009) argued that authentic learning activities are more effective in attitudes towards the course compared to traditional methods. İneç (2017) reported that geo-media-supported authentic learning activities are more effective in increasing students' academic achievement and attitudes towards the course than the traditional method and suggested that these activities should be integrated with technological materials. In an action study, Önger (2019) found that authentic learning activities increase students' motivation for the course, making the topics more concrete, meaningful and fun. The author also reported that students generally enjoyed this practice and wanted to do similar practices; however, some problems such as noise, large class size, seating arrangement, lack of time, the effect of the traditional approach, and the difficulty of the topic were identified during the research process. There exists very limited number of published studies on the use 
of authentic learning activities in the social studies course in the context of Turkey. The present study used a mixed research design to determine student views. It is thereupon hoped that the current study will contribute to the literature.

This study aimed to examine the effect of authentic learning activities on achievement in social studies and attitudes towards GIS. The subproblems of the research are as follows:

- Is there a significant difference between the mean pretest and posttest achievement scores of the experimental group taught using authentic learning activities?

- Is there a significant difference between the mean pretest and posttest achievement scores of the control group taught using the activities in the social studies curriculum?

- Is there a significant difference in the mean posttest achievement scores between the experimental group and the control group?

- Is there a significant difference between the experimental group's mean pretest and posttest scores in the GIS Attitude Scale?

- What are student views on the authentic learning model?

Authentic learning-based teaching was treated as the independent variable, while student achievement and attitudes towards GIS were treated as the dependent variables. The reason for selecting these independent variables is that the researchers believe that authentic learning activities are likely to influence students' achievement and attitudes towards GIS. Goodchild and Kemp (1990) and Keiper (1999) noted that GIS provides authentic environments in which students can collect and produce real data appropriate to their daily lives. Additionally, case studies have shown that a computer can be used as a tool to increase active participation in complex, authentic tasks (Means \& Olson 1994, Jonassen 1996). Alibrandi and PalmerMoloney (2001) also asserted that GIS promotes authentic learning. The experimental procedure was carried out in December in line with the curriculum. Due to the seasonal downsides in December, authentic learning activities were held in the classroom. Geographic Information Systems was planned to be the greatest learning aid for the teacher and students. This technology allows students to see places that they have never seen and attract students' attention, whence facilitates learning.

\section{Methods}

This study used an explanatory mixed methods design which involves quantitative research procedures followed by qualitative research procedures (Creswell \& Plano Clark, 2011). How authentic learning activities and social studies curriculum activities change the learning environment was depicted using quantitative and qualitative data. A quasiexperimental nonequivalent control group pretest-posttest design was referred to in the quantitative phase of the study. The experimental procedure lasted six weeks. The experimental procedure was carried out in two fifth-grade sections which were randomly selected as the experimental group and the control group. Measurement was performed in both groups before and after the experiment. The courses were conducted in the experimental group using authentic learning activities and in the control group using social studies curriculum activities.

In the qualitative phase of the study, the data were collected through semi-structured interviews with nine students in the experimental group. These nine students were selected as follows: three had the highest score on the achievement test, three had the lowest score on the test, and three had a medium score on the test. The findings derived from the quantitative and 
qualitative data were discussed in a unified fashion.

\section{Study Group}

The research population consisted of fifth-grade students in the Central District of Kırşehir in Turkey in the 2019-2020 academic year. The study group consisted of fifth-grade students attending two sections in a public school selected from the population through simple random sampling. The study group consisted of 60 students, the half of whom were in the control group and the other half were in the experimental group. The pretest data were analysed using the independent samples t-test. The analysis results showed no statistically significant difference between the experimental group $(\overline{\mathrm{X}}$ experimental $=9.33)$ and the control group $(\overline{\mathrm{X}}$ control $=10.60)[\mathrm{t}(60)=1.22 ; \mathrm{p}=.227]$. The experimental group had a lower mean rank (29.33) of the pretest scores in the GIS Attitude Scale compared to the control group (31.67) yet the difference was not statistically significant $(\mathrm{U}=415.00 ; \mathrm{Z}=-.52 ; \mathrm{P}=.604$ ). These findings reveal that the experimental and control groups are similar in their achievement in social studies and attitudes towards GIS technology.

\section{Data Collection Instruments Academic Achievement Test}

The social studies academic achievement test resorted to in the study was designed by taking into account the Fifth-Grade Social Studies Curriculum of the 2019-2020 academic year. The questions in the achievement test were developed in line with the learning outcomes that the students were expected to gain during the six-week experimental procedure. A total of 44 four-choice questions were developed by the researchers. The questions were assessed by a social studies education specialist, a social studies teacher, a measurement and evaluation specialist, and a Turkish education specialist. Six questions were removed from the achievement test based on their opinions.

A pilot study was conducted to test the validity and reliability of the achievement test questions. The final form of the achievement test comprises 20 items. For the entire test, the Kuder-Richardson Formula 20 (KR-20) coefficient was .807, the mean value was 14.55 , the variance value was 15.52, and the standard deviation was 3.94. Given that the lower limit of reliability for measurement tools should be 0.70 (Büyüköztürk, 2007), the achievement test is a valid and reliable test to measure academic achievement in social studies.

\section{Geographic Information Systems (GIS) Attitude Scale}

The Geographic Information Systems (GIS) Attitude Scale developed by Baloğlu Uğurlu (2007) is a 5-point Likert-type scale consisting of 20 items (11 positive and 9 negative). The scale is rated as $5=$ strongly agree, $4=$ agree, $3=$ neither agree or disagree, $2=$ disagree, and $1=$ strongly disagree. Negative items are reverse scored. The highest score on the scale is 100 and the lowest is 20 . The attitude scale has three factors that account for 54\% of the variance. Cronbach's alpha was found to be 0.87 for the total scale. The pretest Cronbach's alpha coefficient of the experimental group was .924, while the posttest Cronbach's alpha coefficient was .901. KR-20 coefficient and Cronbach's alpha were found to be above .70 at each measurement. It can then comfortably be said that the achievement test and attitude scale used in this study are reliable measurement tools. 


\section{Semi-Structured Interview Form}

The semi-structured interview technique was used to explore student views on the teaching of the social studies course using the authentic learning model. The intelligibility and suitability of the semi-structured interview form were assessed by two social studies education experts, a social studies teacher, a measurement and evaluation specialist, and a Turkish education specialist. The form was revised based on their feedback. Additionally, a fifth-grade social studies teacher was asked for opinions to determine the intelligibility of the interview questions. Accordingly, the interview form was given its final form. Nine students with different levels of achievement were interviewed using the interview form. Their responses were recorded with their permission as well as that of their parents. The interview form contains the following questions: Did the authentic learning model increase your interest in the course? What do you think about the course and activities you did with the authentic learning model? How do you find the use of GIS software in the social studies course? What are the benefits of the authentic learning model in the social studies course?

\section{Experimental Procedure and Data Analysis}

The experiment was designed as a six-week procedure that continued for eighteen course hours as specified in the Unit "People, Places and Environments" in the Fifth-Grade Social Curriculum. The unit covers the following subjects: "Landforms, the Impact of Climate on Human Activities, Population and Settlement, Disasters and Environmental Problems, and the Impact of Natural Disasters on Our Lives". This very unit is of crucial importance in developing high-level skills. The Ministry of National Education (2018) stipulates that the unit must help students acquire skills such as map literacy, environmental literacy and observation and develop values such as sensitivity to the natural environment and solidarity.

The experimental group was taught using authentic learning activities, while the control group was taught using social studies textbook activities. During the six-week, eighteen-course-hour experimental procedure with the experimental group, the following activities were used: working sheets, crosswords, newspaper clippings, taboo games, stories, videos, census data form, situation assessment report, and painting. The activities were prepared and presented to the students in the context of real-life experiences in keeping with the spirit of authentic learning. The learning outcomes were considered in the design of the activities to keep up with current and controversial issues. In this way, students' curiosity was kept alive during the activities, allowing for different outcomes and solutions. At the beginning of the learning process, the students were helped to recall their prior knowledge to relate it to real-life situations. Careful attention was paid to help the students question topics and transfer their learning to real-life situations. Additionally, during the activities, the learning process was supported by making frequent use of technological facilities, especially GIS. Expert opinion on the activities developed by the researchers was sought from a social studies education specialist, a social studies teacher, a measurement and evaluation specialist, and an educational sciences specialist. Before the experimental procedure, the fifth-grade social studies teacher was informed about the authentic learning model and how activities should be performed. The teacher participated in the experimental procedure voluntarily. The teacher who took charge of the social studies course in the experimental and control groups had 25 years of experience.

The semi-structured interview data were analysed using content analysis. The content analysis of the semi-structured interview data was carried out by the researchers. The researchers 
carried out coding independently of each other. It could arguably be accentuated that the coding in this study is reliable. In content analysis, female students were nicknamed with the letter $\mathrm{F}$ and male students were nicknamed with the letter M. Six students were female and three were male. The quantitative data was analysed using SPSS (IBM), version 23.0. The level of significance was accepted as 0.05 .

\section{Findings}

\section{Findings on the First, Second and Third Sub-Problems:}

To determine which analysis to perform to answer the first, second, and third subproblems of the study, the normality of the data was tested and the KolmogorovSmirnov and the Shapiro-Wilk test results, and skewness and kurtosis values were examined. The analysis results showed that the data were normally distributed. In this regard, a repeatedmeasures ANOVA was performed, and the results were shown in table 1.

Table 1. Results of the Repeated-Measures ANOVA.

\begin{tabular}{cccccccc}
\hline $\begin{array}{c}\text { Source of } \\
\text { Variation }\end{array}$ & $\begin{array}{c}\text { Sum of } \\
\text { Squares }\end{array}$ & df & $\begin{array}{c}\text { Mean } \\
\text { Square }\end{array}$ & F & P & $\begin{array}{c}\text { Significant } \\
\text { Difference }\end{array}$ & 耳2 \\
\hline Pre-Post-Pre-Post & 561.768 & 3 & 187.253 & 12.328 & .000 & $1-2$ & .298 \\
Error & 1321.492 & 87 & 15.190 & & & & \\
Total & 1883.260 & 90 & & & & & \\
\hline
\end{tabular}

The Mauchly's test of sphericity results validated the repeated measures ANOVA (W (5) = 807; $\mathrm{p}=0.312$ ). Accordingly, there was a significant difference between the mean pretest and posttest scores of the experimental and control groups and the effect size of the difference is large $(F(3 ; 87)=12.328 ; p=0.000 ; \eta 2=0.298)$. The Bonferroni multiple comparison test was used to find the source of variation. In this sense there was a difference between the mean pretest and posttest scores of the experimental group was in favour of the posttest (X 9.33; $\bar{X}$ posttest $=15.13$ ). A difference was also found between the mean posttest scores of the experimental group and the mean pretest scores of the control group (X)posttest $=15.13$; $\bar{X}$ pretest $=10.60$ ) in favour of the mean posttest scores of the experimental group. Nevertheless, there was no statistically significant difference between the mean pretest and posttest scores of the control group $(\overline{\mathrm{X}}$ pretest $=10.60 ; \overline{\mathrm{X}}$ posttest $=12.10)$. There was a difference, but not statistically significant, between the mean posttest score ( $\bar{X}$ posttest $=$ $15.13)$ of the experimental group and the mean posttest score ( $\bar{X}$ postttest $=12.10)$ of the control group in favour of the experimental group. Based on the eta-squared value, it can be expressed that the activities performed in accordance with the authentic learning model had a high-level positive $(\eta 2=.298)$ effect on students' achievement in social studies.

\section{Findings on the Fourth Subproblem}

To determine which analysis to perform to answer the fourth subproblem of the study, the normality of the data was tested and the Kolmogorov-Smirnov and the Shapiro-Wilk test results, and skewness and kurtosis values were examined. The analysis results showed that the data were normally distributed. Therefore, the dependent samples t-test was performed, and the results are shown in table 2. 
Table 2. T-Test results.

\begin{tabular}{ccccccccc}
\hline Groups & Test & $\mathbf{N}$ & $\overline{\mathbf{X}}$ & SD & df & t & P & Cohen's d \\
\hline \multirow{2}{*}{ Experimental } & Pretest & 30 & 80.83 & 15.65 & 29 & 4.16 & .001 & \multirow{2}{*}{0.358} \\
& Posttest & 30 & 85.73 & 11.43 & & & & \\
\hline
\end{tabular}

The t-test results indicated that the mean score of the experimental group on the attitude scale statistically significantly increased from Xpretest $=80.83$ to Xposttest $=5.73$ and that the effect size of the difference is medium $(t(29)=4.16 \mathrm{p}=.001$ Cohen's $d=0.358)$.

\section{Findings on the Fifth Subproblem}

The fifth subproblem of the study is "What are student views on the authentic learning model?". Nine students, including six females and three males, were interviewed. Semistructured interviews were held with nine students. The interview data were analysed using content analysis. Table 3 presents the analysis results.

Table 3. Student views on the authentic learning.

\begin{tabular}{|c|c|c|c|}
\hline Themes & Categories & Codes & Student Nicknames \\
\hline \multirow{11}{*}{$\begin{array}{l}0 \\
. \\
\vdots \\
0 \\
0 \\
\Xi \\
0 \\
0 \\
0 \\
0 \\
0 \\
0 \\
0 \\
0\end{array}$} & \multirow{4}{*}{$\begin{array}{l}\text { Student Motivation } \\
\text { Interest in the Course }\end{array}$} & Active learning & $\begin{array}{l}\text { F1, F2, F3, M4, M5, } \\
\text { F6, F7, F8, M9 }\end{array}$ \\
\hline & & Fun learning & $\begin{array}{l}\text { F1, F2, F3, M4, M5, } \\
\text { F7, F8, M9 }\end{array}$ \\
\hline & & Arousing curiosity & F3, M4, M9 \\
\hline & & Belief in success & M2 \\
\hline & \multirow{4}{*}{ Benefits of GIS } & Locations explored & $\begin{array}{l}\text { F1, F2, F3, M5, F6, } \\
\text { F7, F8 }\end{array}$ \\
\hline & & Permanent Learning & F1, F6, M9 \\
\hline & & Bringing distant places nearer & $\mathrm{F} 1, \mathrm{~F} 2, \mathrm{M} 5$ \\
\hline & & Learning landforms & F2, M9 \\
\hline & \multirow{3}{*}{ Academic Achievement } & Recalling knowledge & F3, M4, M5, F6 \\
\hline & & Exam success & M4, M6, M9 \\
\hline & & $\begin{array}{l}\text { Fast Learning } \\
\text { No memorisation }\end{array}$ & $\begin{array}{l}\text { F3, F8 } \\
\text { F6, M9 }\end{array}$ \\
\hline \multirow{3}{*}{ 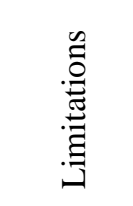 } & \multirow{3}{*}{ Student Expectations } & Insufficient course hours & $\mathrm{F} 1, \mathrm{M} 4, \mathrm{~F} 6$ \\
\hline & & Continuation of activities & $\mathrm{F} 2, \mathrm{M} 4, \mathrm{~F} 6$ \\
\hline & & $\begin{array}{l}\text { Authentic learning in different } \\
\text { courses }\end{array}$ & F3, M4, F8 \\
\hline
\end{tabular}

F: Female, M: Male 
The views of nine students on the authentic learning model were grouped into four categories under two themes. In tandem with the statements of each student, the codes were classified into categories thematically. These categories include "student motivation and interest in the course, benefits of GIS, academic achievement, and student expectations". "Student motivation and interest in the course" has the highest number of codes (f: 21 ), while "student expectations" has the lowest number of codes (f: 9).

Student views on the contribution of authentic learning to the course consisted of the codes "active learning (9), fun learning (8), arousing curiosity (3), and belief in success (1)". These codes were subsumed under the category "student motivation and interest in the course". Below are the reasons that the students reported for each code:

"We were always studying before; thanks to these activities, our classes are more fun. I do not get bored but rather enjoy learning” (F1).

"I used to think social studies was boring, but now I enjoy it and I think I will be successful" (F2, M9).

"I did not enjoy the social studies course, but now I enjoy it. Listening to the lecturing alone was very boring at first, but the classes have become more enjoyable thanks to the activities and my interest has increased a lot" (F3).

"I never get bored with this course and 40 minutes session is like a one minute long one" (M5).

In light of the students' views on authentic learning, they previously found the course boring because they used to study continuously without activities, but now the course was not boring; on the contrary, interesting thanks to the activities they did. They also voiced that as they enjoyed the course, they had fun while learning, their interest in the course increased, and they believed that they would be successful in the course.

Student views on the contribution of authentic learning to the course also included the codes "locations explored (7), permanent learning (3), bringing distant places nearer (3), and learning landforms (2)". These codes were subsumed under the category "benefits of GIS". Below are the reasons that the students reported for each code:

"Using GIS, I have gained all the geographic information I did not know. GIS brings distant places near to us" (F1).

"We can check the places we want to travel to and learn about their geographical location and landforms immediately. It is like going to places we do not know, to the places we have not seen. It is like as if even faraway places are coming to us" (F2).

"With GIS, I have seen plains, mountains, and rivers I have never been to. When you see faraway places, it feels as if you were going there. Now I can see any place in the world" (M5).

"I like the GIS software because it showed us places we did not know" (F6). 
Given the students' views on authentic learning, they expressed that they felt like distant places became closer since thanks to GIS, they discovered some faraway places that they had not seen before and therefore they loved this activity. They also shared that they could see any place on Earth that they like to see, and they could learn about landforms more quickly.

Student views on the contribution of authentic learning to the course also included the codes "recalling knowledge (3), exam success (3), fast learning (2) and no memorisation (2)". These codes were subsumed under the category "academic achievement". Below are the reasons that the students reported for each code:

"I do not forget the subjects thanks to GIS. When I am asked about these, I answer immediately" (F1).

"I could keep the subjects we were taught in my mind for a longer time. I could learn without getting bored or memorizing” (F2, F7).

"It was a very fun process. So, my achievement increased, and my exam grades were higher in this course" (M4).

"I easily retained most of the information in my mind. I am better prepared for exams. When the teacher asks questions, I give better answers.

I make fewer mistakes in exams" (F6).

"I used to have difficulty solving questions about social studies and now I am better. I answered all the exam questions pertinent to this unit" (M9).

Students told that they learned the topics without having to memorise them or without getting bored, they did not forget what they learned, and they could answer the questions about the topics presented. They also stressed that the process was really entertaining, they made fewer mistakes in the tests and exams and that their success levels increased.

Student views on the limitations of authentic learning consisted of the codes "insufficient course hours (3), continuation of activities (3), and authentic learning in different courses (3)". These codes were subsumed under the category "student expectations". Below are the reasons that the students reported for each code:

"Social studies lasts three hours, so I did not have time to play taboo. Sometimes I did it at home because I did not have time" (F1).

"I think authentic learning should be used for every course" (F8).

"I think I will understand more quickly if such activities are always used in social studies or in other courses" (F3).

"I want authentic learning processes to continue and to be used in other courses" (M4).

"I want authentic learning classes to continue. I want to do more activities and have more social studies courses" (F6). 
Students articulated that they could not finish some activities because the course hours of social studies were insufficient, and they completed these activities at home. They also emphasized that such activities should continue and be also used in other courses.

In general, under the category "student motivation and interest in the course", it was concluded that the students are not bored by the course thanks to the classroom activities, they enjoy the course, they have fun and are more active in the class, and they think they will be successful in the course. Under the category of "benefits of GIS", it was determined that the students have seen and learned distant landforms that they had not had the chance to see and their learning was better and more permanent. Under the category "academic achievement", it was found out that the classes taught using the authentic learning model increased students' achievement in exams and tests and the students learned the subjects without memorizing and do not forget them thanks to the activities. Under the category of "student expectations", it was found that the course hours of social studies are insufficient for activities and authentic learning activities should also be employed in courses other than social studies.

\section{Discussion}

A significant difference was found between the mean pretest and posttest achievement scores of the experimental group taught using authentic learning activities and the difference has a large effect size. However, there was no significant difference between the mean pretest and posttest achievement scores of the control group taught using the activities in the social studies curriculum. The analysis results showed an increase in the mean achievement score of the control group; however, this was not significant. These results are consistent with earlier studies reporting that authentic learning activities increase academic achievement (Aydin, 2019; Aynas, 2018; Bay, 2008; Dadl1, 2017; Finch \& Jefferson, 2013; Gençoğlan, 2017; Hürsen, 2016; İneç, 2017; Johnson, 2007; Koçyiğit, 2011; Koçyiğit \& Zembat, 2013; Niesz, 2003; Saye \& SSIRC, 2013). Previous studies have also shown than authentic learning facilitates learning (Gürdoğan \& Aslan, 2016), makes subjects more understandable (Akça \& Ata, 2009) and effectively improves the learning experience (Safuan \& Soh, 2013).

This study detected a significant difference between the mean pretest and posttest GIS Attitude Scale scores of the experimental group taught using authentic learning activities. The effect size of the difference was medium. This result is in accord with prior studies indicating that authentic learning activities significantly have a positive impact on attitudes towards courses (Aynas, 2018; Baştürk, 2019; Belaid \& Murray, 2015; Dilmaç \& Dilmaç, 2014; Horzum \& Bektaş, 2012; Hürsen, 2016; İneç, 2017; Koçyiğit, 2011), promotes student satisfaction (Horzum \& Bektaş, 2012; Wornyo, Klu, \& Motlhaka, 2018), and increases student motivation (Gündoğan, 2014; Gürdoğan \& Aslan, 2016; Önger, 2019). Yeen-Ju, Mai, and Selvaretnam (2015) found supportive evidence for the use of authentic learning strategies in technology-supported classrooms in higher education institutions. Chen et al. (2013) created a digital learning platform to provide an authentic learning environment in the classroom and found that the students became more willing to participate in classroom activities and deeply enjoyed the learning process. Boyac1 and Güner (2017) reported that primary school students enjoyed doing activities in an authentic learning environment through a blog page that combines the internet and the course, and they were happy that these activities are seen by everyone. It has also been shown that GIS activities enhance student motivation (Aksoy, 2004; Aladağ, 2007) and enrich the learning environment (Çepni, 2013)

In the qualitative phase, the study investigated student views on the authentic learning model 
through semi-structured interviews. The interview data were analysed through content analysis and the following categories were created: "student motivation and interest in the course, benefits of GIS, academic achievement, and student expectations". The analysis results showed that the students did not get bored with social studies rather liked and enjoyed the course. They thought that they would be successful and participated in the course more actively thanks to the activities they did in the classroom. They could see landforms that they had not seen and learned better through GIS. They achieved more permanent learning. They found the social studies course hours insufficient for the authentic learning activities. They thought that authentic learning activities should be used in other courses as well as social studies. These results support previous research indicating that authentic learning activities are fun (Hamurcu, 2016), encourage students to participate more actively in classes (Çoşkun et al., 2017; Ulusoy, 2012), increase students' motivation (Motlhaka, 2014; Westberg \& Leppien, 2018), develop problem-solving, strategic thinking and communication skills (Anwari et al., 2015), foster collaboration (Keinänena et al., 2018), result in a high level of interaction in the learning environment (Luo et al., 2017), promote problem-solving, critical thinking, creative thinking and communication skills (Yeen-Ju et al., 2015), have a positive effect on students' perceived self-efficacy (Karakoç, 2016), facilitate associating course subjects with real-life situations (Aynas, 2018; Weninger, 2018), provide students with a unique learning experience in an authentic world (Gregory, 2013), and produce a positive change in students' cognitive levels (Aydın et al., 2018). Dennis and O'Hair (2010) noted that the greatest obstacle for authentic learning is the lack of time to design materials and the authentic learning process requires more time for preparation and planning.

\section{Conclusion}

A search of the literature revealed few studies on the authentic learning model in the field of social studies. With that being said, the literature includes no research on the effect of authentic learning on attitudes towards GIS. Hence, this study fills a gap in the literature via investigating the effect of authentic learning activities on achievement in social studies and attitudes towards GIS. The strengths of the study included the use of a mixed methods research design and multiple data collection tools, the calculation of effect size scores, and the arguments about the theoretical framework. Within the scope of the study, it was observed that authentic activities and GIS were in good harmony. Student views also demonstrated that the use of technology increased the motivation for the course.

\section{Limitations and Recommendations}

Apart from the above-listed strengths, this study has some limitations. The study sampled only fifth-grade students and further research may collect data from different samples. It is in particular important to plan authentic learning activities that do not have a single correct answer. Activities should be designed to help students develop a different perspective on subjects. In this way, students improve their questioning, criticism, and reflective thinking skills and their ability to respect others' ideas. The use of other disciplines such as science and mathematics with an interdisciplinary approach during authentic learning activities is helpful and attracts students' attention. Further studies may also investigate whether the authentic learning model has an impact on the skills in the curriculum. Plans of authentic learning activities may be shared for teachers on digital platforms such as Education Information Network (EBA in its Turkish acronym). 


\section{References}

Akça, N., \& Ata, B. (2009). Application and problems of authentic activities in high school history courses, new trends in education. 5. Nature of Learning and Evaluation Symposium, İzmir Private Tevfik Fikret Schools, İzmir.

Akkuş, Z. (2015). Activity-based teaching in social studies education: An action research. Educational Research and Reviews, 10(14), 1911-1921. http://doi.org/10.5897/ERR2015.2261

Aksoy, B. (2004). A model of the teaching of geographical information systems. Kastamonu Education Journal, 12(1), 179-190.

Aladağ, E. (2007). The effect of geographic information system in teaching social studies to the academic achievements and motivation of 7th grade students of primary education. (Unpublished Doctoral Thesis). Gazi University, Ankara.

Alibrandi, M., \& Palmer Moloney, J. (2001). Making a place for technology in teacher education with Geographic Information Systems (GIS). Contemporary Issues in Technology and Teacher Education, 1(4), 483-500.

Altın, B. N., \& Atçı, A. Ş. (2012). Sosyal bilgiler dersinde sınıf dışı eğitim etkinlikleri [Outof-class educational activities in social studies]. In M. Safran (Ed.), Sosyal bilgiler öğretimi [Teaching social studies] (pp. 545-583). Ankara: Pegem Academy

Altın, M. (2019). An example application performed with Algo-Heuristic teaching theory and the effect of the application on the level of success. Studies in Educational Research and Development, 3(2), 23-42.

Ataizi, M., \& Şimşek, A. (1999). Regulation of situational learning environments in basic education. Kurgu Journal, (16), 255-266.

Aydin, O. (2019). The impact of authentic learning environments on the 4. classroom mathematics course success and academic self-confidence. (Unpublished Doctoral Thesis). Burdur Mehmet Akif Ersoy University, Burdur.

Aydın Aşk, Z., \& Bay, E. (2018). Evaluation of authentic task-oriented learning processes in 7th grade mathematics (action research). Adnan Menderes University Education Faculty Journal of Educational Sciences, 9(1), 95-112.

Aykaç, N. (2007). The teacher'opininons about the elementary social science lesson. Electronic Journal of Social Sciences,6(22), 46-73.

Aynas, N. (2018). An investigation of the effect of authentic learning practise in science course. (Unpublished Doctoral Thesis). Van Yüzüncü Y1l University, Van.

Baloğlu Uğurlu, N. (2007). The Effects on student attitude and achievement to teaching of geographic information systems supported subject of Turkey's natural resources in social studies courses. (Unpublished Doctoral Thesis). Gazi University, Ankara.

Baştürk, G. (2019). Impact of authentic learning practices on students' critical thinking skills and attitudes towards social studies. (Unpublished Master Thesis). Sakarya University, Sakarya.

Bay, E. (2008). Evaluation of the effectiveness of constructivist curriculum applications in teacher education. (Unpublished Doctoral Thesis). Atatürk University, Erzurum.

Baysal, Z. N., Çarıkçı, S., \& Yaşar, B. (2018). Analysis of academics' views on teaching thinking skills. Inonu University Journal of the Faculty of Education (INUJFE), 19(2).174-188. https://doi.org/10.17679/inuefd.339151

Bektaş, M., \& Horzum, M. B. (2014). Otantik öğrenme [Authentic learning]. Ankara: Pegem Academy.

Belaid, A. M., \& Murray, L. (2015). Using authentic materials in the foreign language classrooms: Teacher attitudes and perceptions in Libyan Universities. International Journal of Learning and Development, 5(3), 25-37. https://doi.org/10.5296/ijld.v5i3.8218 
Belet Boyac1, Ş., \& Güner, M. (2017). Views of students and teachers about use of technological authentic environment in Turkish language course. Anadolu Journal of Educational Sciences International, 7(1), 35-71.

Bozu, E. (2014). Application and evaluation of situational learning approach in learningteaching environment. (Unpublished Master Thesis). Firat University, Elazığ.

Brown, J. S., Collinns, A., \& Duguid, P. (1989). Situated cognition and the culture of learning. Educational Researcher, 18(1), 32-42. https://doi.org/10.3102/0013189X018001032

Büyüköztürk, Ş. (2007). Sosyal bilimler için veri analizi el kitabı [Handbook of data analysis for the social sciences]. Ankara: PegemA Publ.

Çelik, Ö., Esmer, B., \& Yılmaz, E. (2016). Perceptions of primary school teacher candidates on teaching values. Turkish Studies, 11(19), 229-244. https://doi.org/10.7827/TurkishStudies.9995

Chen, G, D., Nurkhamid, Wang, C, Y., Yang, S, H., Lue, W, Y. \& Chang, C, K. (2013). Digital learning playground: Supporting authentic learning experiences in the classroom. Interactive Learning Environments, 21(2), 172-183.

Coşkun, H., Doğan, A., \& Uluay, G. (2017). The effect of technology on students opinions about authentic learning activities in science courses. Universal Journal of Educational Research, 5(1), 72-83.

Cotofana, S., \& Lachman, N. (2020). The superficial face dissection as an example for integrating clinical approaches, authentic learning, and changing perspectives in anatomy dissection. Anatomical Sciences Education, 13(1), 117-121.

Creswell, J. W., \& Plano Clark, V. L. (2011). Mixed method research. Thousand Oaks, CA: Sage Publ.

Çepni, O. (2013). The use of geographic information systems (GIS) in geography teaching. World Applied Sciences Journal, 25(12), 1684-1689.

Dadl1, G. (2017). The effect of learning activities based on authentic problems in the human and environmental relations unit on the reflective thinking skills, academic success, environmental attitude and awareness of 7 th grade students. (Unpublished Master Thesis). Kahramanmaraş Sütçü İmam University, Kahramanmaraş.

Dennis, J., \& O'Hair, M. J. (2010). Overcoming obstacles in using authentic instruction; A comparative case study of high school math and science teachers. American Secondary Education, 38(2), 4-22.

Dilmaç, S., \& Dilmaç, O. (2014). Attitudes of authentic assessment approach of visual arts lesson in high school. Dokuz Eylül University Buca Education Faculty Journal, (38), $1-35$.

Dolapçığlu, S. (2015). The development of critical thinking in mathematics classes via authentic learning: An action. (Unpublished Doctoral Thesis). Çukurova University, Adana.

Duman, B., \& İkiel, C. (2002). Social studies as to constructivist learning and teaching theory. Firat University Journal of Social Science, Elazığ, 12(2), 245-262.

Firat, M. (2008). Second Life ve sanal ortamda otantik ögrenme deneyimleri [Authentic learning experiences in second life and virtual environment]. 25th National Informatics Congress, Ankara.

Finch, J. L., \& Jefferson, R. N. (2013). Designing authentic learning tasks for online library instruction. The Journal of Academic Librarianship, 39(2), 181-188.

Flanagan, WGT. (2014). Creating authentic learning environments in a grade 10 economics classroom via a progressive teaching design. (Unpublished Master Thesis). University of South Africa, Pretoria. 
Gençoğlan, D. M., (2017). The effects of argumentation based science learning (ABSL) approach based on authentic case studies on the success, attitude and scientific process skills of 8th grade students in the acids and bases lesson. (Unpublished Master Thesis). Kahramanmaraş Sütçü İmam University, Kahramanmaraş.

Goodchild, M. F., \& Kemp, K. K. (Eds.). (1990). NCGIA core curriculum in GIS, national center for geographic information and analysis. Santa Barbara CA: University of California.

Gökdaş, İ. (2003). Effect of computer and classroom settings based situated learning on student success, attitude and transfer. (Unpublished Doctoral Thesis). Ankara University, Ankara.

Gregory, S. (2013). Exploring authentic learning activities for enhanced learning outcomes: adult learners and their perceptions of learning in a virtual world. (Unpublished Doctoral Thesis). University of New England, Armidale.

Gulikers, J. T. M., Bastiaens, T. J., \& Martens, R. L. (2005). The surplus value of an authentic learning environment. Computers in Human Behavior, 21, 509-521.

Gündoğan, A., \& Gültekin, M. (2017). Hayat bilgisi dersinde otantik görev temelli öğrenme ortamlarının oluşturulmasına yönelik örnek uygulamalar [Sample applications for creating authentic task-based learning environments in life science course]. İn Ö. Demirel, S. Dinçer (Eds.), Küreselleşen Dünyada Eğitim [Education in a Globalizing World] (pp. 779-792). Ankara: Pegem Atıf Index.

Gürdoğan, M., \& Aslan, A. (2016). Classroom teacher candidates' views on authentic learning approach. Journal of Science Education, 4(2), 114-140.

Gürgil, F. (2018). The effect of authentic learning approach in social studies teaching on the academic success. Universal Journal of Educational Research 6(10), 2061-2068.

Hamurcu, G. C. (2016). The effect of authentic learning on students' problem solving and reading comprehension skills, as well as their attitude towards the course in elementary education's 7th grade Turkish language course. (Unpublished Doctoral Thesis). İnönü University, Malatya.

Herrington, J., \& Oliver, R. (1995). Critical characteristics of situated learning: Implications for the instructional design of multimedia. Paper presented at ASCILITE ${ }^{\text {ee } 95}$ Conference, Melbourne.

Herrington, J., \& Oliver, R. (2000). An instructional design framework for authentic learning environments. Educational Technology Research and Development, 48(3), 23-48. https://doi.org/10.1007/BF02319856

Herrington, J., Reeves, T. C., \& Oliver, R. (2010). A guide to authentic e-learning. London: Routledge.

Herrington, J., Reeves, T. C., \& Oliver, R. (2014). Authentic learning environments. In J. Michael Spector, M. David Merrill and M. J. Bishop (Eds.), Handbook of research on educational communications and technology (pp. 401-412). New York: Springer.

Horzum, M., \& Bektaş, M. (2012). The effect of authentic learning on preservice teachers' attitude and satisfaction towards service learning. Kastamonu Education Journal, 20(1), 341-360.

Hürsen, Ç. (2016). The impact of curriculum developed in line with authentic learning on the teacher candidates' success, attitude and self- directed learning skills. Asia Pacific Educ. Rev. 17, 73-86. https://doi.org/10.1007/s12564-015-9409-2

İneç, Z. F. (2017). The effectiveness of geo-media assisted authentic learning environment on learning on the social studies lessons. (Unpublished Doctoral Thesis). Erzincan University, Erzincan.

İneç, Z. F., \& Akpınar, E. (2017). New approaches in authentic teaching of social studies. International Journal of Social Science Research, 6(2), 46-65. 
Johnson, Y. L. (2007). The efficacy of authentic assessment versus pencil and paper testing in evaluating student achievement in a basic technology course. (Unpublished Doctoral Thesis). Walden University, Minnesota.

Jonassen, D. (1996). Computers in the classroom: Mindtools for critical thinking. Engelwood, New Jersey: Prentice-Hall.

Kab, İ., \& Açıkalın, M. (2016). Real life activities in social studies education: Examples from Germany, United States and Japan. National Education Journal, 45(211), 45-61.

Karakoç, B. (2016). Investigating the effectiveness of the authentic task based practices to the foreign language teaching. (Unpublished Doctoral Thesis). Gaziantep University, Gaziantep.

Karakuş, F. (2006). The Effect of constructivist learning and authentic assessment approach on social studies teaching students' academic achievement retention and attitudes towards social studies. (Unpublished Doctoral Thesis). Çukurova University, Adana.

Keinänena, M., Ursin, J., \& Nissinen, K. (2018). How to measure students' innovation competences in higher education: Evaluation of an assessment tool in authentic learning environments. Studies in Educational Evaluation, 58, 30-36.

Keiper, T. A. (1999). GIS for elementary students: An inquiry into a new approach to learning geography. Journal of Geography, 98(2), 47-59.

Keskin, F. (2017). The effectiveness of context-based react strategy on 6th grade students' academic achievement and scientific literacy. (Unpublished Master Thesis). Muğla Sitkı Koçman University, Muğla.

Kılıç, E. (2004). Status and importance of situated learning theory in education. Gazi Faculty of Education Journal, 24(3), 307-320.

Kıliç, M. A. (2015). The effect of contextual teaching and learning approach on the 7th grade primary school students' mathematics achievement, mathematics attitude and transferring mathematics to the real life problems. (Unpublished Doctoral Thesis), Erzincan University, Erzincan.

Kılıçoğlu, G. (2014). Sosyal bilgiler tanımı, dünyada ve ülkemizde gelişimi ve önemi [Definition of social studies, its development and importance in the world and in our country.]. İn M. Safran (Ed), Sosyal bilgiler öğretimi [Teaching social studies] (pp. 316). Ankara: Pegem Publ.

Koçyiğit, S. (2011). The effects of the authentic task based constructivist approach on preservice teachers' achievement, attitudes towards classes and problem solving skills. (Unpublished Doctoral Thesis). Marmara University, İstanbul.

Koçyiğit, S., \& Zembat, R. (2013). The effects of the authentic task on preservice teachers' achievement. Hacettepe University Journal of Education, 28(3), 291-303.

Lave, J., \& Wenger E. (2003). Situated learning: Legitimate peripheral participation. Cambridge: Cambridge University Press.

Luo, T., Murray, A., \& Crompton, H. (2017). Designing authentic learning activities to train pre-service teachers about teaching online. International Review of Research in Open and Distance Learning, 18(7), 141-157. https://doi.org/10.19173/irrodl.v18i7.3037

Means, B., \& Olson, K. (1994). The link between technology and authentic learning. Educational Leadership 51(7), 15-18.

The Ministry of Education, (2018). Sosyal bilgiler dersi ögretim programı (ilkokul ve ortaokul 4, 5, 6 ve 7. siniflar) [Social studies course curriculum (primary and secondary schools 4, 5, 6 and 7. Classes)]. Ankara: State Books of the Ministry of Education.

Motlhaka, H. A. (2014). Authentic learning: Bridging the gap of knowledge and action in south African higher education. Mediterranean Journal of Social Sciences, 5(23). 891896. 
Newmann, F. M., \& Welhage, G. G. (1993). Five standards for authentic instruction. Educational Leadership, 50(7), 8-12.

Niesz, T. M. (2003). The Project approach to learning: How the project approach provides opportunities for authentic learning, (Unpublished Master Thesis). Pacific Lutheran University, Washington.

Önger, S. (2019). The authentic learning approach in social studies teaching: An action research study. (Unpublished Doctoral Thesis). Gazi University, Ankara.

Preus, B. (2012). Authentic instruction for 21st century learning: Higher order thinking in an inclusive school. American Secondary Education, 40(3), 59-79.

Rule, A.C. (2006). Editorial: The components of authentic learning. Journal of Authentic Learning, 3(1), 1-10.

Safuan, H. A. J., \& Soh, R. (2013). The integration of authentic learning principles and facebook in service learning. TOJET: The Turkish Online Journal of Educational Technology, 12(4), 192-199.

Saye, J., \& Social Studies Inquiry Research Collaborative (SSIRC). (2013). Authentic pedagogy: Its presence in social studies classrooms and relationship to student performance on state-mandated tests. Theory \& Research in Social Education, 41(1), 89-132. https://doi.org/10.1080/00933104.2013.756785

Tekin, H. (2000). Eğitimde ölçme ve değerlendirme [Measurement and evaluation in education]. Ankara: Yarg1 Publ.

Ulusoy, G. (2012). Authentic video use in high school English courses: An empirical study on the effect of situation comedy on speaking. (Unpublished Master Thesis). Süleyman Demirel University, Isparta.

Yalçınkaya, E., \& Azrak, Y. (2016). The opinions of social studies teachers on children councils: A qualitative study. Zeitschrift für die Welt der Türken/Journal of World of Turks, 8(1), 151-169.

Yalvaç Hastürk, H. G. (2013). Investigating and assessing the changes in the teacher candidates' cognitive structures about some environmental topics in authentic learning environments. (Unpublished Doctoral Thesis). Gazi University, Ankara.

Yanti, P. G., \& Mulyono, H. (2020). Incorporating a smartphone video in a theatrical activity to promote an authentic language learning environment in a lower secondary school classroom. International Journal of Interactive Mobile Technologies (IJIM), 14(01), 141-151.

Yeen-Ju, H. T., Mai, N., \& Selvaretnam, B. (2015). Enhancing problem-solving skills in an authentic blended learning environment: A Malaysian context. International Journal of Information and Education Technology, 5(11), 841-846. https://doi.org/1010.7763/IJIET.2015

Yıldırım, A., \& Şimşek, H. (2009). Sosyal bilimlerde nitel araştırma yöntemleri [Qualitative research methods in social sciences]. Ankara: Seçkin Publ.

Weninger, C. (2018). Problematising the notion of 'authentic school learning': Insights from student perspectives on media/literacy education. Research Papers in Education, 33(2), 239-254. https://doi.org/10.1080/02671522.2017.1286683

Westberg, K., \& Leppien, J. (2018). Student independent investigations for authentic learning. Gifted Children, 41(1), 13-18. https://doi.org/10.1177/1076217517735354

Wornyo, A. A., Klu, E. K., \& Motlhaka, H. (2018). Authentic learning: Enhancing learners' academic literacy skills. International Journal of Applied Linguistics \& English Literature, 7(4), 56-61. http://dx.doi.org/10.7575/aiac.ijalel.v.7n.4p.56 